\title{
Effect of some Biological Stimulants and Kaolin Particles Sprays on Fruit Retention, Productivity and Fruit Quality of Washington Navel Orange Trees
}

\author{
Mohamed S. M. Ali ${ }^{1}$ and Hamdy E. El Zayat ${ }^{2}$ \\ ${ }^{1}$ Department of Horticulture, Faculty of Agriculture, Suez Canal University, Ismailia, Egypt \\ ${ }^{2}$ Department of Fruit Handling, Horticulture Research Institute, ARC, Giza, Egypt.
}

Received: $21 / 4 / 2019$

\begin{abstract}
This investigation was performed out during seasons 2016 and 2017 at private grove in El-Salhia El-Gadida, Sharkia Governorate, Egypt on 11 year-old Washington navel orange trees are growing in sandy soil under drip irrigation system. The effects of spraying salicylic acid (SA) (200 and $400 \mathrm{mg} / \mathrm{L})$, Jasmine oil (JO) (2 and $4 \mathrm{ml} / \mathrm{L}$ ), radish root extract (RRE) (50 and $100 \mathrm{ml} / \mathrm{L})$ and Kaolin particles film (KPF) $(5000$ and $10000 \mathrm{mg} / \mathrm{L})$ were studied on vegetative growth (leaf area index and leaf chlorophyll value), fruit set, fruit retention, productivity (yield as number and weight per tree), fruit quality parameters (fruit weight, fruit diameter, secondary fruit diameter, peel thickness, firmness, juice content, TSS, TA, TSS/TA ratio, ascorbic acid) and nutritional status (N, P, K and Ca contents). The current study clearly demonstrated that SA at all concentrations especially at $200 \mathrm{mg} / \mathrm{L}$ improved leaf area index, fruit retention, fruit number per tree, fruit yield, fruit firmness, juice content percentage, TSS, ascorbic acid and decreased the total acidity in orange juice, as well as increased nutritional status (N and $\mathrm{P})$,. Also, a positive response in fruit retention, fruit weight, peel thickness, leaf area, chlorophyll value and $\mathrm{N}$ and $\mathrm{P}$ contents by foliar application of KPF at all concentrations under study. Moreover, Foliar sprays with $\mathrm{JO}$ at $2 \mathrm{ml} / \mathrm{l}$ and RRE at $100 \mathrm{ml} / \mathrm{l}$ significantly increased fruit set, fruit weight, fruit diameter, peel thickness, and lowered acidity percentage and increased Ca content.
\end{abstract}

Keywords: Navel orange, salicylic acid, Jasmine oil, Jasmonic acid, radish root extract, kaolin, fruit quality

\section{INTRODUCTION}

Orange occupies the first rank among all fruits cultivated in Egypt, with about more than four million metric tons produced in 2015 (El-Boray et al., 2015), and Egypt exports of orange exceeded 1.6 million tons in 2016/2017 (USDA 2016, 2017 and 2018). Navel orange is the most important citrus fruit in Egypt. The flowers, fruitlets and fruit quality are sensitive to adverse climatic and soil conditions. Thus, yield of Washington navel orange trees growing in sandy soil conditions are usually reduced by sever shedding of flowers and fruitlets and lower fruit quality. Efforts should be exerted constantly to increase cultivated area, production, and improve fruit quality of Navel orange in order to satisfy local consumption and increasing demands on Egyptian oranges in international markets.

Biological stimulants such as salicylic acid, Jasmine oil and radish root extract in addition to kaolin particles show some effects on both vegetative growth and production of fruit trees (Kittikorn and Kanlayanarat, 2004; Schaller and Stintzi, 2009; Zarins et al., 2009; Glenn and Puterka, 2010; Sabry et al., 2011; Schlink, 2011; El-Zayat et al., 2017).

Salicylic acid (SA) is a natural phenolic compound that plays a vital role in mitigating biotic and abiotic stresses in plants. Foliar spraying of salicylic acid is effective in controlling tree growth and increase productivity when applied on orange and Kinnow mandarin trees (Ashraf et al., 2013; ElGioushy, 2016).

Jasmine oil (JO) or Jasmonate as a plant substance may play a role in plant development under various physiological biotic and abiotic stresses (Vick, 1984; Schlink 2011; Ismail et al., 2012). JO effects related genes which have illustrated a substantial role in enhancing fruit yield and quality in many plants under different conditions (Ahmed et al., 2016). Jasmonic acid treatment in lower concentrations on grapevines encouraged flowering, improved percentage of bud burst and good yield with high bunch quality (Sanders et al., 2000; Piotrowska et al., 2009) and on date palm according to Zaki et al. (2017).

Radish is an important Genus in Brassicaceae family as well as It is a source of medicinally important substances isothiocyanates and peroxidases (Curtis, 2003). Radish roots (Raphanus sativus) extracts (RRE) have very useful components which have cysteine as antimicrobial substance used on tomatoes, cucumbers, peppers (Zarins et al., 2009). In addition, Root extract illustrated higher antifungal activity under various concentrations where reduced fungal biomass on plants (Javaid and Bashir, 2018).

Kaolin particle film (KPF) is a natural mineral extracted in Egypt and from other countries used mainly insect control, anti-sunburn agent and has some physiological effects of drought and heat stress on crops. In addition, repelling grasshoppers, leaf rollers, mites, thrips and some moth varieties, psylla, flea beetles (Rosati, 2007; Braham et al., 2007; Skewes, M. 2014). Kaolin treatment at different concentrations increased fruit firmness of navel orange (Ali and Elhamahmy, 2015) and protected of sunburn for Balady mandarin (Ennab et al., 2017) and apple fruits (Glenn and Puterka, 2010).

Hence, this research work was undertaken to investigate the effect of salicylic acid, Jasmine oil, radish root extract as a biological stimulants and kaolin particles as a natural mineral under fruit against trees factors (temperature and lack of irrigation) on vegetative growth, fruit set, fruit retention, productivity and fruit quality of Washington navel orange. 


\section{MATERIALS AND METHODS}

This work was conducted during two successive seasons 2016 and 2017 on 11-year-old trees of Washington navel orange (Citrus sinensis L. Osbeck) budded on sour orange. The trees grown in sandy soil under drip irrigation system at a private grove, ElSalhia El-Gadida, Sharkia Governorate, Egypt. Navel orange trees were planted at $5 * 5$ meters apart and subjected the same annual horticultural management. The complete randomized block design was used, where the experiment involved 9 treatments, having four replicates with one tree in each. The treatments included the foliar applications of salicylic acid (SA) at 200 and $400 \mathrm{mg} / \mathrm{L}$; Jasmine oil (JO) at 2 and $4 \mathrm{ml} / \mathrm{L}$;
Radish root extract (RRE) at 50 and $100 \mathrm{ml} / \mathrm{L}$; Kaolin particle film (KPF) at 5000 and $10000 \mathrm{mg} / \mathrm{L}$; control (the water treated trees). Treatments were applied five times to selected trees at full bloom stage and continuing periodically once every 15 -day- intervals. A single spray with $\approx 5.0$ liters of solution per tree in the morning of a day using handgun sprayer. Tween- 80 at $0.03 \%$ as wetting agent was used with the applied solutions before spraying.

From the orchard soil, sample was taken at 50 $\mathrm{cm}$ depth to determine physico-chemical properties and stipulated in Table (1) (Nelson and Sommers, 1982; Jackson, 1962).

Table (1): Soil composition used in this study

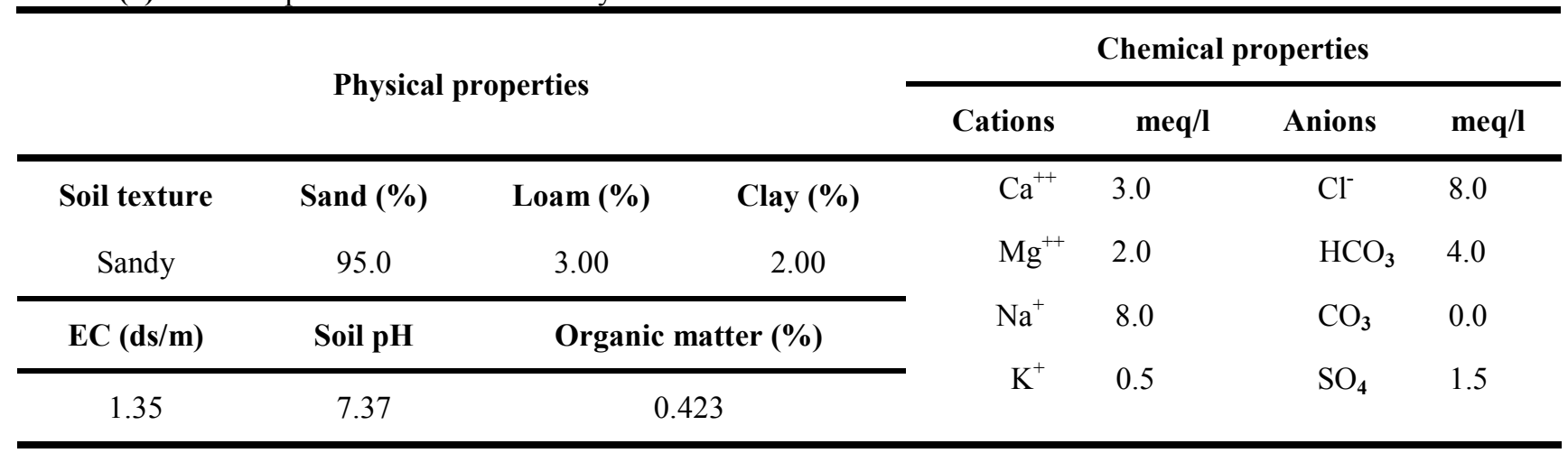

Four branches of three years of age having similarities in vigour and size were chosen and labeled per tree in early spring of both seasons and the following parameters were studied.

\section{Initial fruit set and retained fruit percentage:}

Initial fruit set and fruit retention percentages were determined by counting the initial number of flowers at full bloom on the selected branches and number of fruitlets after 15 days from full bloom. Retained fruit on selected branches periodically calculated up to harvest according to Westwood (1978) and Khan et al. (2009) as follow:

\section{Total number of fruitlets}

$$
\text { Fruit set }(\%)=\frac{-}{\text { Total number of flowers }}
$$

Total number of retained fruit at subsequent dates

\section{Fruit retention $(\%)=$ \\ Total number of fruitlets}

Fruit yield: At harvest date, yield per tree was estimated by fruit number and fruit weight and expressed in $\mathrm{kg}$.

Fruit quality: Samples of 15 fruits were randomly selected at harvest time from each tree to determine fruit dimensions, secondary fruit diameter navel diameter), and peel thickness by using digital vernier caliper and expressed as $\mathrm{cm}$. Firmness $\left(\mathrm{kg} / \mathrm{cm}^{2}\right)$ of peeled fruit of navel orange on the two opposite sides of each fruit was measured by using a hand Magness
Taylor pressure tester, fitted with a $0.7 \mathrm{~cm}$ convex plunger.

Fruit Juice content (\%) was extracted and calculated using the equation: (Juice fruit weight/fruit weight) $\mathrm{x}$ 100.

Total Soluble solids (TSS \%) estimated by using Digital refractometer (LCII, Medline scientific, RS-95, United Kingdom) at room temperature.

Total acidity (TA \%): Titratable acidity was determined in fruit juice as percentage of citric acid by titration against $0.1 \mathrm{~N}$ of $\mathrm{NaOH}$ using phenolphthalein indicator (AOAC, 1995).

TSS/TA ratio was calculated by dividing the percentage of TSS on TA values.

Vitamin C value (VC): Ascorbic acid was estimated using titration with 2,6-dichlorophenolendophenl dye as $\mathrm{mg} / 100 \mathrm{ml}$ juice (AOAC, 1995).

\section{Vegetative determinations:}

Leaf Chlorophyll content: total chlorophyll contents were measured in 20 fresh leaves per tree $\left(6^{\text {th }}\right.$ leave from the base on the shoot), using Minolta meter SPAD-502 (Benedict and Swidler, 1961; Peterson et al., 1993).

Vegetative growth and nutrient contents: From the middle of non-fruiting shoots $\left(6^{\text {th }}\right.$ leave from the base on the shoot), twenty five mature leaves of 5-6 months old, growing from spring growth flush, were randomly taken from each tree at the last week of July in both seasons to determine the following:

Leaf area index: it was measured using the Planimeter (No. 19723, JOPAT, Japan) and expressed as $\mathrm{cm}^{2}$. 
Leaf nutrient contents: Leaves were carefully cleaned, rinsed with distilled $\mathrm{H}_{2} \mathrm{O}$, dried at $70^{\circ} \mathrm{C}$, ground, thinned and digested according to Chapman and Pratt (1961). Leaf content percentages of N, P, K, Ca and Na were determined using various methods (Karla, 1998; Wilde et al., 1985).

\section{Statistical Analysis:}

Data obtained were statistically analyzed and significant differences between different treatments means were determined by using Least Significant Difference test (LSD at 0.05) according to Steel et al. (1997).

\section{RESULTS AND DISCUSSION}

\section{Effect on fruit set and fruit retention:}

Initial fruit set and retained fruit percentages are shown in Table (2). It is evident that all concentrations of SA, JO, RRE, and KPF significantly increased the percentage fruit set after 15 days from full bloom than the control in the two seasons. Both Radish root extracts at $100 \mathrm{mlL}^{-1}$ and Jasmine oil at $4 \mathrm{mlL}^{-1}$ gave the highest fruit set \% after 15 days from full bloom (14.57 and 14.24) in the first season and (14.59 and 14.80) in the second season, respectively. Preceding results followed by SA treatment at $400 \mathrm{mg} / \mathrm{L}$ and Jasmine oil at $2 \mathrm{mlL}^{-1}$ where significantly increased fruit set \% (14.64 and 14.52) in the second season compared to the control. On the other hand, KPE treatments improved slightly fruit set \% by 12.18 and 14.13 compared to control (11.10 and 12.10, respectively) in two seasons. The final fruit setting is controlled by the capacity of the tree to supply metabolites to developing fruitlets during post anthesis, and by the climate and orchard management.
Concerning retained fruit (Table 2), all investigated treatments enhanced the percentage of fruit retention at certain intervals after full bloom in comparison with the control during 2016 and 2017 seasons. Thereafter, the percentages were sharply decreased within 02 July and 10 July during both seasons and remained nearly steady after that up to harvest. These lower percentages of fruit set during May and June months may be a result of severe competition between flowers and fruitlets for water, nutrition and unfavorable weather condition during this period. SA at $200 \mathrm{mg} / \mathrm{l}$ had the highest effect of increasing percent of fruit retained during different ages of fruit development compared with all of the other treatments in both seasons. Meanwhile, treatment with $\mathrm{JO}$ at $2 \mathrm{ml} / 1$ or KPF at $5000 \mathrm{mg} / \mathrm{l}$ and $10000 \mathrm{mg} / \mathrm{l}$ resulted in significantly highest percentages of retained fruit at most stages of fruit development in 2016 and 2017 seasons.

The obtained results was in line with mentioned by Ruiz et al. (2001) who cited that after 30 days of flower opening, fruitlets retention was around 13\%, and consistent also with the results of Zaghloul and Moursi (2017) who cited that navel orange set reached about $(6.3 \%-7.8 \%)$ when counted at end of June (after about 60 days from full bloom). SA may be significantly decreased the accumulation of the gene transcripts of auxin-responsive, GH3-like protein and 12-oxo-PDA reductase, but resulted in higher percentages of young fruit retention in citrus trees according to Lahey et al. (2004) and Ashraf et al. (2013) on Kinnow mandarin. In contrast, no significant difference of Jasmonic acid was noticed in citrus flower or fruit set.

Table (2): Effect of some biological stimulants and kaolin particles on initial fruit set (\%); fruit retention (\%) of Washington navel orange at different periods of development during 2016 and 2017 seasons

\begin{tabular}{|c|c|c|c|c|c|c|c|c|c|c|c|}
\hline \multirow{3}{*}{\multicolumn{2}{|c|}{ Treatments, Conc. }} & \multirow{2}{*}{\multicolumn{2}{|c|}{$\begin{array}{c}\text { Fruit set (\%) } 15 \\
\text { DAFB }\end{array}$}} & \multicolumn{8}{|c|}{ Fruit retention (\%) DAFB } \\
\hline & & & & \multicolumn{4}{|c|}{2016} & \multicolumn{4}{|c|}{2017} \\
\hline & & 2016 & 2017 & 03 May & 03 June & 02 July & 15 Oct. & 11 May & 10 June & 10 July & 28 Oct. \\
\hline \multirow{2}{*}{ SA } & $200 \mathrm{mgL}^{-1}$ & $13.22 \mathrm{c}$ & $14.00 \mathrm{c}$ & $21.72 \mathrm{a}$ & $12.19 \mathrm{a}$ & $7.85 \mathrm{a}$ & $5.19 \mathrm{a}$ & $21.99 \mathrm{a}$ & $11.14 \mathrm{~b}$ & $7.98 \mathrm{a}$ & $5.36 \mathrm{a}$ \\
\hline & $400 \mathrm{mgL}^{-1}$ & $14.00 \mathrm{~b}$ & $14.64 \mathrm{ab}$ & $12.84 \mathrm{c}$ & $10.59 \mathrm{bc}$ & $4.10 \mathrm{e}$ & $2.91 \mathrm{~cd}$ & $19.20 \mathrm{~b}$ & $9.79 \mathrm{c}$ & $4.64 \mathrm{~cd}$ & $3.10 \mathrm{~d}$ \\
\hline \multirow{2}{*}{ JO } & $2 \mathrm{mlL}^{-1}$ & $13.29 \mathrm{c}$ & $14.52 \mathrm{ab}$ & $16.27 \mathrm{~b}$ & $11.70 \mathrm{a}$ & $6.99 b$ & $3.90 \mathrm{~b}$ & $16.91 \mathrm{c}$ & $10.64 b$ & $7.02 b$ & $4.51 \mathrm{~b}$ \\
\hline & $4 \mathrm{mlL}^{-1}$ & $14.24 \mathrm{ab}$ & $14.80 \mathrm{a}$ & $13.18 \mathrm{c}$ & $9.55 \mathrm{~d}$ & $5.44 d$ & $4.05 b$ & $15.80 \mathrm{~d}$ & $9.74 \mathrm{c}$ & $6.41 b$ & $4.04 \mathrm{bc}$ \\
\hline \multirow{2}{*}{ RRE } & $50 \mathrm{mlL}^{-1}$ & $14.01 \mathrm{~b}$ & $14.28 \mathrm{bc}$ & $11.05 \mathrm{~d}$ & $8.89 \mathrm{e}$ & $3.81 \mathrm{ef}$ & $3.04 \mathrm{c}$ & $14.42 \mathrm{e}$ & $9.32 \mathrm{c}$ & $4.97 \mathrm{c}$ & $3.73 \mathrm{c}$ \\
\hline & $100 \mathrm{mlL}^{-1}$ & $14.57 \mathrm{a}$ & $14.59 \mathrm{ab}$ & $12.16 \mathrm{~cd}$ & $11.31 \mathrm{ab}$ & $3.39 \mathrm{fg}$ & $2.39 \mathrm{~cd}$ & $13.64 \mathrm{e}$ & $10.73 b$ & $4.19 \mathrm{~d}$ & $3.01 \mathrm{~d}$ \\
\hline \multirow{2}{*}{ KPF } & $5000 \mathrm{mgL}^{-1}$ & $12.18 \mathrm{~d}$ & $12.73 d$ & $15.74 \mathrm{~b}$ & $10.39 b c$ & $6.06 \mathrm{c}$ & $5.49 \mathrm{a}$ & $16.60 \mathrm{~cd}$ & $10.93 b$ & $6.50 \mathrm{~b}$ & $4.16 \mathrm{bc}$ \\
\hline & $10000 \mathrm{mgL}^{-1}$ & $13.08 \mathrm{c}$ & $14.13 \mathrm{c}$ & $15.46 \mathrm{~b}$ & $10.92 b$ & $5.84 \mathrm{~cd}$ & $5.08 \mathrm{a}$ & $17.35 \mathrm{c}$ & $12.04 \mathrm{a}$ & $6.98 \mathrm{~b}$ & $4.15 b c$ \\
\hline \multicolumn{2}{|c|}{ Control } & $11.10 \mathrm{e}$ & $12.10 \mathrm{e}$ & $11.17 \mathrm{~d}$ & $10.14 \mathrm{~cd}$ & $3.14 \mathrm{~g}$ & $2.24 \mathrm{~d}$ & $13.49 \mathrm{e}$ & $9.47 \mathrm{c}$ & $4.17 \mathrm{~d}$ & $2.73 d$ \\
\hline \multicolumn{2}{|c|}{ Mean } & 13.29 & 13.97 & 14.31 & 10.71 & 5.18 & 3.81 & 16.60 & 10.42 & 5.67 & 3.87 \\
\hline \multicolumn{2}{|c|}{ L.S.D at $0.05 \%$} & 0.95 & 0.65 & 0.95 & 0.65 & 0.53 & 0.71 & 0.97 & 0.76 & 0.62 & 0.60 \\
\hline
\end{tabular}




\section{Fruit yield and fruit number per tree:}

Fruit number per tree, fruit weight, yield per tree and per feddan are presented in Table (3). Data showed that SA at $200 \mathrm{mg} / 1$ had the highest fruit number per tree (196.75 and 207.50 fruits) in two seasons, respectively compared to the other treatments and control. Preceding results followed by application SA $(400 \mathrm{ml} / \mathrm{l})$ where significantly increased fruit number per tree with compared the control in the two seasons. On the other hand, both JO (4 ml/l) and KPF (10000 $\mathrm{mg} / \mathrm{l})$ only enhanced fruit number/tree in the first season. In general, all concentrations of biological stimulants and kaolin increased fruit number per tree in both seasons.

Fruit weight as shown in Table (3), indicated that all investigated treatments under study improved fruit weight than the control except salicylic acid at $200 \mathrm{mg} / \mathrm{l}$, which failed to show any significant effect during 2016 and 2017 seasons. The maximum value of fruit weight was achieved with KPF at $5000 \mathrm{mg} / 1$ (362.64 and $367.88 \mathrm{~g})$ during two seasons in comparison with the control (325.58 and $331.78 \mathrm{~g}$ ), respectively. JO at $4 \mathrm{ml} / 1$ and/or RRE at $100 \mathrm{ml} / 1$ followed KPF treatment in improving av. Fruit weight than that of untreated trees in the two seasons.

SA at both concentrations $(200 \mathrm{mg} / \mathrm{l}$ and 400 $\mathrm{mg} / \mathrm{l})$ and $\mathrm{JO}(4 \mathrm{ml} / \mathrm{l})$ gave the highest fruit yield per tree (64.56; 64.46 and 66.69 in 2016 season and 69.33; 70.79 and 69.68 in 2017 season), respectively and therefore, increasing productivity for feddan. All used biological stimulants and Kaolin increased navel orange yield expressed as the number of fruit and weight than the control.

These results were in harmony with finding of Ashraf et al. (2013) who cited that spraying SA significantly improved fruit yield on Kinnow mandarin trees.

Table (3): Effect of some biological stimulants and kaolin particles on Fruit weight; Fruit number and yield/tree of Washington navel orange at different periods of development during 2016 and 2017 seasons

\begin{tabular}{|c|c|c|c|c|c|c|c|c|c|}
\hline \multicolumn{2}{|c|}{ Treatments, Conc. } & \multirow{2}{*}{$\begin{array}{c}\begin{array}{c}\text { Fruit } \\
\text { number/ } \\
\text { tree }\end{array} \\
2016\end{array}$} & \multirow{2}{*}{$\begin{array}{c}\begin{array}{c}\text { Fruit } \\
\text { weight }(\mathrm{g})\end{array} \\
2016\end{array}$} & \multirow{2}{*}{$\begin{array}{c}\begin{array}{c}\text { Yield/tree } \\
(\mathrm{kg})\end{array} \\
2016\end{array}$} & \multirow{2}{*}{$\begin{array}{c}\begin{array}{c}\text { Yield fed }^{-1} \\
\text { (ton) }\end{array} \\
2016\end{array}$} & \multirow{2}{*}{$\begin{array}{c}\begin{array}{c}\text { Fruit } \\
\text { number/ } \\
\text { tree }\end{array} \\
2017\end{array}$} & \multirow{2}{*}{$\begin{array}{c}\begin{array}{c}\text { Fruit } \\
\text { weight (g) }\end{array} \\
2017\end{array}$} & \multirow{2}{*}{$\begin{array}{c}\begin{array}{c}\text { Yield/ tree } \\
(\mathrm{kg})\end{array} \\
2017\end{array}$} & \multirow{2}{*}{$\begin{array}{c}\begin{array}{c}\text { Yield } \\
\text { fed }^{-1} \\
\text { (ton) }^{-}\end{array} \\
2017\end{array}$} \\
\hline & & & & & & & & & \\
\hline \multirow{2}{*}{$\mathbf{S A}$} & $200 \mathrm{mgL}^{-1}$ & $196.75 \mathrm{a}$ & $328.15 \mathrm{e}$ & $64.56 \mathrm{ab}$ & $10.85 \mathrm{ab}$ & $207.50 \mathrm{a}$ & $334.07 f$ & $69.33 a$ & $11.65 \mathrm{a}$ \\
\hline & $400 \mathrm{mgL}^{-1}$ & $186.50 \mathrm{~b}$ & $345.60 \mathrm{c}$ & $64.46 \mathrm{ab}$ & $10.83 \mathrm{ab}$ & $199.75 b$ & $354.38 \mathrm{bc}$ & $70.79 a$ & $11.89 \mathrm{a}$ \\
\hline \multirow{2}{*}{ JO } & $2 \mathrm{mlL}^{-1}$ & $167.50 \mathrm{de}$ & $341.89 \mathrm{~cd}$ & $57.26 \mathrm{c}$ & $9.62 \mathrm{c}$ & $173.00 \mathrm{fg}$ & $347.35 d$ & $60.08 \mathrm{c}$ & $10.10 \mathrm{c}$ \\
\hline & $4 \mathrm{mlL}^{-1}$ & $187.25 b$ & $356.20 \mathrm{~b}$ & $66.69 \mathrm{a}$ & $11.20 \mathrm{a}$ & $194.25 \mathrm{c}$ & $360.25 b$ & $69.98 \mathrm{a}$ & $11.76 \mathrm{a}$ \\
\hline \multirow{2}{*}{ RRE } & $50 \mathrm{mlL}^{-1}$ & $172.00 \mathrm{~cd}$ & $337.25 \mathrm{~d}$ & $58.00 \mathrm{c}$ & $9.75 \mathrm{c}$ & $178.75 \mathrm{e}$ & $341.13 \mathrm{e}$ & $60.98 \mathrm{c}$ & $10.24 \mathrm{c}$ \\
\hline & $100 \mathrm{mlL}^{-1}$ & $177.75 \mathrm{c}$ & $358.18 \mathrm{ab}$ & $63.68 b$ & $10.70 \mathrm{~b}$ & $183.75 \mathrm{~d}$ & $357.58 b$ & $65.70 \mathrm{~b}$ & $11.04 b$ \\
\hline \multirow{2}{*}{ KPF } & $5000 \mathrm{mgL}^{-1}$ & $174.25 \mathrm{c}$ & $362.64 \mathrm{a}$ & $63.19 \mathrm{~b}$ & $10.62 b$ & $177.5 \mathrm{ef}$ & $367.88 \mathrm{a}$ & $65.30 \mathrm{~b}$ & $10.97 \mathrm{~b}$ \\
\hline & $10000 \mathrm{mgL}^{-1}$ & $184.50 \mathrm{~b}$ & $345.88 \mathrm{c}$ & $63.82 \mathrm{~b}$ & $10.72 b$ & $191.25 \mathrm{c}$ & $350.05 \mathrm{~cd}$ & $66.95 \mathrm{~b}$ & $11.24 \mathrm{~b}$ \\
\hline \multicolumn{2}{|c|}{ Control } & $163.00 \mathrm{e}$ & $325.58 \mathrm{e}$ & $53.08 \mathrm{~d}$ & $8.92 d$ & $172.00 \mathrm{~g}$ & $331.78 \mathrm{f}$ & $57.07 \mathrm{~d}$ & $9.59 \mathrm{~d}$ \\
\hline \multicolumn{2}{|c|}{ L.S.D at $0.05 \%$} & 6.53 & 5.93 & 2.58 & 0.43 & 4.81 & 5.95 & 1.87 & 0.31 \\
\hline
\end{tabular}

Values followed by the same letter within a column are not significantly different at LSD, $\mathrm{P} \leq 0.05$ level of probability

All treatments were beneficial in increasing fruit yield in different ways and mechanisms. Foliar sprays SA on Valencia trees had significantly increased yield, fruit weight, and reducing drop $\%$, owing to salicylic acid effect in enhancing metabolism of plants and biosynthesis during fruit development (Habasy, 2015). Kucuker and Ozturk (2014) cited that preharvest applying methyl Jasmonate on Japanese plums had resulted in higher yield because of its regulatory role in fruit growth and ripening. Foliar application of JO as reported by Iqbal et al. (2012) increased fruit weight and this effect is due to enhancing resistance against pests and citrus green and blue molds on tree and that lead to reinvigorating leaves so that photosynthesis will be kept in high rates. The present results contradict the findings of Jifon and Syvertsen (2003) and Zaghloul et al. (2017) who concluded that Spraying Balady mandarin with $1,2,3$, and $4 \%$ of KPF increased the yield especially at $4 \%$. This effect may be due to the protective effect of kaolin against high temperature fluctuations and other stresses. In addition to a possible effects in increasing photosynthesis of sprayed leaves. RRE was effective because of its contents of pesticide, antifungal, and antibacterial materials as caffeine and ferulic acids (Gutierrez and Perez, 2004).

\section{Physical characteristics:}

Physical fruit characteristics of navel orange are shown in Table (4). Regarding fruit dimensions, data concluded that all treatments caused a significant increase in average fruit length and average fruit width compared to the control. Spraying RRE at $100 \mathrm{ml} / \mathrm{l}$ caused the largest increase in fruit length and fruit width $\left(9.33\right.$ and $8.60 \mathrm{~cm}$ at the $1^{\text {st }}$ season and 9.69 and 
$8.65 \mathrm{~cm}$ at the $2^{\text {nd }}$ season, respectively) compared to the other treatments and untreated ones $(8.71$ and 8.27 $\mathrm{cm}$ and 8.98 and $8.28 \mathrm{~cm}$ in both seasons, respectively). In addition, kaolin particle film at 5000 $\mathrm{mg} / \mathrm{l}$ or $\mathrm{JO}(4 \mathrm{ml} / \mathrm{l})$ followed by RRE treatment at 100 $\mathrm{ml} / \mathrm{l}$ in this respect. Fruit diameter slightly and insignificantly improved by salicylic acid sprays,
Radish root extract treatment at $50 \mathrm{ml} / \mathrm{l}$ and JO $(2 \mathrm{ml} / \mathrm{l})$ as compared to the control during 2016 and 2017.

Other treatments resulted in intermediary results of fruit length and width. RRE resulted in higher fruit size and this is consistent with the results of Zarins et al. (2009) and that may explain the high growth rate of orange fruits from treated trees.

Table (4): Effect of some biological stimulants and kaolin particles on fruit physical determinations of Washington navel orange during 2016 and 2017 seasons

\begin{tabular}{|c|c|c|c|c|c|c|c|c|c|c|c|}
\hline \multirow{2}{*}{\multicolumn{2}{|c|}{ Treatments, Conc. }} & $\begin{array}{c}\text { Fruit } \\
\text { length } \\
\text { (cm) }\end{array}$ & $\begin{array}{l}\text { Fruit } \\
\text { width } \\
\text { (cm) }\end{array}$ & $\begin{array}{c}\text { Secondary } \\
\text { fruit } \\
\text { diameter } \\
(\mathrm{cm}\end{array}$ & $\begin{array}{l}\text { Firmmess } \\
\left.(\mathrm{kg} \mathrm{cm})^{-2}\right)\end{array}$ & $\begin{array}{l}\text { Peel } \\
\text { thickness } \\
\text { fruit (cm }\end{array}$ & $\begin{array}{c}\text { Fruit } \\
\text { length } \\
\text { (cm) }\end{array}$ & $\begin{array}{l}\text { Fruit } \\
\text { width } \\
\text { (cm) }\end{array}$ & $\begin{array}{c}\text { Secondary } \\
\text { fruit } \\
\text { diameter } \\
\text { (cm) }\end{array}$ & $\begin{array}{l}\text { Firmness } \\
\left(\mathrm{kg} \mathrm{cm}^{-2}\right)\end{array}$ & $\begin{array}{c}\text { Peel } \\
\text { thickness } \\
\text { fruit }(\mathrm{cm})\end{array}$ \\
\hline & & & & 2016 & & & & & 2017 & & \\
\hline \multirow{2}{*}{$\mathbf{S A}$} & $200 \mathrm{mgL}^{-1}$ & $\begin{array}{c}8.92 \mathrm{~cd} \\
\mathrm{e}\end{array}$ & $8.31 \mathrm{~cd}$ & $0.89 \mathrm{~cd}$ & $5.14 \mathrm{a}$ & $0.47 b$ & $9.14 b c$ & $8.32 b c$ & $0.51 \mathrm{f}$ & $4.12 \mathrm{a}$ & $0.46 \mathrm{c}$ \\
\hline & $400 \mathrm{mgL}^{-1}$ & $\begin{array}{c}8.95 \mathrm{~cd} \\
\mathrm{e}\end{array}$ & $\begin{array}{c}8.34 b c \\
d\end{array}$ & $0.74 f$ & $5.16 \mathrm{a}$ & $0.44 \mathrm{c}$ & $9.45 \mathrm{ab}$ & $\begin{array}{c}8.52 \mathrm{ab} \\
\mathrm{c}\end{array}$ & $0.40 \mathrm{~g}$ & $4.12 \mathrm{a}$ & $0.45 \mathrm{c}$ \\
\hline \multirow{2}{*}{ JO } & $2 \mathrm{mlL}^{-1}$ & $8.72 \mathrm{e}$ & $8.49 \mathrm{ab}$ & $0.98 b$ & $5.04 \mathrm{ab}$ & $0.48 b$ & $8.98 \mathrm{c}$ & $\begin{array}{c}8.43 \mathrm{ab} \\
\mathrm{c}\end{array}$ & $1.25 \mathrm{~b}$ & $4.01 \mathrm{ab}$ & $0.49 b$ \\
\hline & $4 \mathrm{mlL}^{-1}$ & $\begin{array}{c}9.10 \mathrm{ab} \\
\mathrm{c}\end{array}$ & $8.52 \mathrm{a}$ & $0.99 b$ & $4.89 b c$ & $0.43 \mathrm{~cd}$ & $9.47 \mathrm{ab}$ & $8.55 \mathrm{ab}$ & $1.02 \mathrm{c}$ & $3.88 \mathrm{~b}$ & $0.45 \mathrm{c}$ \\
\hline \multirow{2}{*}{ RRE } & $50 \mathrm{mlL}^{-1}$ & $8.79 \mathrm{de}$ & $8.19 \mathrm{~d}$ & $0.63 \mathrm{~g}$ & $4.67 \mathrm{de}$ & $0.48 b$ & $9.07 \mathrm{c}$ & $8.55 \mathrm{ab}$ & $0.63 \mathrm{~h}$ & $3.61 \mathrm{c}$ & $0.51 \mathrm{ab}$ \\
\hline & $100 \mathrm{mlL}^{-1}$ & $9.33 \mathrm{a}$ & $8.60 \mathrm{a}$ & $1.58 \mathrm{a}$ & $4.47 \mathrm{f}$ & $0.51 \mathrm{a}$ & $9.64 \mathrm{a}$ & $8.65 \mathrm{a}$ & $1.46 \mathrm{a}$ & $3.41 \mathrm{~d}$ & $0.52 \mathrm{a}$ \\
\hline \multirow{2}{*}{ KPF } & $5000 \mathrm{mgL}^{-1}$ & $9.22 \mathrm{ab}$ & $\begin{array}{c}8.46 a b \\
c\end{array}$ & $0.78 \mathrm{ef}$ & $4.76 \mathrm{~cd}$ & $0.53 \mathrm{a}$ & $9.52 \mathrm{a}$ & $8.67 \mathrm{a}$ & $0.75 \mathrm{e}$ & $3.34 \mathrm{~d}$ & $0.52 \mathrm{a}$ \\
\hline & $10000 \mathrm{mgL}^{-1}$ & $\begin{array}{c}8.99 b c \\
d\end{array}$ & $8.49 \mathrm{ab}$ & $0.91 b c$ & $4.54 \mathrm{ef}$ & $0.42 \mathrm{~cd}$ & $9.43 \mathrm{ab}$ & $\begin{array}{c}8.42 \mathrm{ab} \\
\mathrm{c}\end{array}$ & $0.90 \mathrm{~d}$ & $3.49 \mathrm{~cd}$ & $0.40 \mathrm{~d}$ \\
\hline \multicolumn{2}{|c|}{ Control } & $8.71 \mathrm{e}$ & $8.27 \mathrm{~d}$ & $0.83 \mathrm{de}$ & $4.14 \mathrm{~g}$ & $0.41 \mathrm{~d}$ & $8.98 \mathrm{c}$ & $8.28 \mathrm{c}$ & $0.77 \mathrm{e}$ & $3.12 \mathrm{e}$ & $0.41 \mathrm{~d}$ \\
\hline \multicolumn{2}{|c|}{ L.S.D at $0.05 \%$} & 0.24 & 0.18 & 0.08 & 0.19 & 0.03 & 0.34 & 0.24 & 0.04 & 0.18 & 0.02 \\
\hline
\end{tabular}

Values followed by the same letter within a column are not significantly different at L.S.D, P $\leq 0.05$ level of probability

Radish extracts contain cysteine rich peptides and isocyanates which have a certain growth effect and are used commercially in producing plant biostimulants.

Therefore, radish extracts helps in the availability of stimulating conditions, which contribute to improve growth of orange fruits. As for the secondary fruit, it is well known and accepted that the smaller secondary fruit on navel orange, the better the quality of this fruit. After calculation of regression equation, between the fruit weight and the secondary fruit diameter, it was found a weak correlation factor $(\mathrm{R}=0.27)$. Radish extract treatment $(100 \mathrm{ml} / \mathrm{l})$ resulted in higher fruit weight in both seasons, but accompanied by the highest values of secondary fruit diameter ( 1.58 and $1.46 \mathrm{~cm}$ ) for both seasons, respectively.

JO treatment with both $2 \mathrm{ml} / 1$ and $4 \mathrm{ml} / 1$ and kaolin $(10000 \mathrm{mg} / \mathrm{l})$ followed by RRE $(100 \mathrm{ml} / \mathrm{l})$ with a big secondary fruit $(0.9-1.25 \mathrm{~cm}$ in diameter $)$.

Fruit firmness (Table 4) was significantly increased by most investigated treatments in both seasons, except with RRE at $100 \mathrm{ml} / 1$ in the first season. The highest fruit firmness was determined from trees sprayed with $200 \mathrm{mg} / \mathrm{l}$ or $400 \mathrm{mg} / \mathrm{l}$ of SA, followed by $\mathrm{JO}$ at $2 \mathrm{ml} / \mathrm{l}$ treatment than of the check treatment in the two seasons.
Peel thickness (Table 4) of control was lower than all of other treatments fruit recording $0.41 \mathrm{~cm}$ in both seasons and similar only to fruits of kaolin treatment at $10000 \mathrm{mg} / \mathrm{l}$. Radish extract $(100 \mathrm{ml} / \mathrm{l})$ and kaolin treatment $(5000 \mathrm{mg} / \mathrm{l})$ recorded the highest thickness of peel in range from 0.51 to $0.53 \mathrm{~cm}$ in both seasons. Most probably used by a higher rate of nitrogen and potassium absorption by the trees as stimulated by spraying radish extract and kaolin treatments (Bevingron et al., 1993).

It can be concluded here that radish extract treatment had resulted in bigger fruits containing a clear secondary fruit, while exogenous application of Jasmonate at early stage of fruits development has protected them against various stresses (Mirdehghan et al., 2012). And that contributes to a regular and optimum fruit growth and consequently, a fruit of high caliber (size) of moderate rind thickness $(0.43-0.49$ $\mathrm{cm})$. SA treatment gave fruits of moderate size but in the second season they have the smallest secondary fruit $(0.51$ and $0.40 \mathrm{~cm}$ for low and high conc., respectively among all treatments.

The high firmness of SA treatment fruit may be explained by the fact that SA may induce a high acquired resistance in plants, which to a vital factor in limiting the injurious effects of abiotic stresses and 
inhibiting water loss from fruits. these results are in accordance with those of Ahmad et al. (2013) in their work on sweet orange with concentrations of 2, 4, 6, and $8 \mathrm{~mm}$ of ascorbic acid and in which the lower concentration $2 \mathrm{~mm}$ gave the second highest firmness values of fruit which corroborate the values of fruit firmness related to JO treatment are supported by the similar results obtained by Kucuker and Ozturk (2014) reporting that Jasmonate treated trees of Prunus salicina (plums) resulted in higher yields and increasing fruit firmness.

Kaolin sprays on navel orange in this experiment has delayed the ripening processes of orange and these results are in accordance with the work of Zaghloul et al. (2017) on Balady mandarin and also are supported by the results of Maletiska et al. (2015) on clingstone peach displaying a higher value of firmness for kaolin treated fruits compared to control. Balbontín et al. (2018) concluded that application methyl Jasmonate on sweet cherry increased firmness of fruits indicating that Jasmonic acid influences physiological processes of ripening by delaying softening as it is involved in the regulation of cell wall metabolism genes.

SA and radish extract treatments came afterwards with lower and similar firmness values in both seasons. Control fruits were more developed and reached a more advanced stage of ripening, therefore they have the lowest firmness of pulp.
Effect of treatments on juice content, TSS, acidity and vitamin $\mathrm{C}$ :

Table (5) showed that there were highly significant differences among the treatments in all studied traits. It clearly demonstrated that the trees treated by SA at $400 \mathrm{mg} / \mathrm{L}$ achieved the highest significant values of juice content in both seasons. While, the lowest value of juice content was recorded with application of RRE at $50 \mathrm{ml} / \mathrm{L}$ in a comparison with control. It also indicated that the highest TSS percentage and TSS/TA ratio were obtained in trees subjected to foliar application of SA at $200 \mathrm{ml} / \mathrm{L}$ followed by SA at $400 \mathrm{mg} / \mathrm{L}$ and $\mathrm{JO}$ at $2 \mathrm{ml} / \mathrm{L}$ during both growing seasons compared to other treatments. In addition, Table 5 showed that the TA (\%) was significantly decreased with foliar application SA and RRE compared to untreated trees, whereas the lowest TA was recorded treated trees by SA at $200 \mathrm{mg} / \mathrm{l}$ and RRE at $100 \mathrm{ml} / \mathrm{L}$ in both seasons. Finally, ascorbic acid as shown in Table 5 indicated that all concentrations of SA, JO at $2 \mathrm{ml} / \mathrm{L}$ improved ascorbic content. The highest values were obtained in trees treated with $200 \mathrm{mg} / \mathrm{L}$ of SA compared to other treatments.

These results are in agreement with Lahey et al. (2004) and Ashraf et al. (2013) on kinnow mandarin and El-Gioushy (2016) on navel orange, who found that the SA at different concentration enhanced the chemical characteristics; juice content (\%), TSS (\%), vitamin C $(\mathrm{mg} / 100 \mathrm{~g})$ and decreased citric acid (\%).

Table (5): Effect of some biological stimulants and kaolin particles on fruit chemical determinations of Washington navel orange during 2016 and 2017 seasons

\begin{tabular}{|c|c|c|c|c|c|c|c|c|c|c|}
\hline \multirow[t]{2}{*}{ Treatments, Conc. } & $\begin{array}{c}\text { Juice } \\
\text { content } \\
(\%) \\
\end{array}$ & TSS (\%) & TA $(\%)$ & $\begin{array}{c}\text { TSS/TA } \\
\text { ratio }\end{array}$ & $\begin{array}{c}\text { V.C } \\
(\mathrm{mg} / 10 \\
0 \mathrm{~g} \text { FW) } \\
\end{array}$ & $\begin{array}{c}\text { Juice } \\
\text { content } \\
(\%) \\
\end{array}$ & $\begin{array}{l}\text { TSS } \\
(\%)\end{array}$ & $\begin{array}{c}\text { TA } \\
(\%)\end{array}$ & $\begin{array}{c}\text { TSS/TA } \\
\text { ratio }\end{array}$ & $\begin{array}{c}\text { V.C } \\
\text { (mg/100 } \\
\text { g FW) } \\
\end{array}$ \\
\hline & & & 2016 & & & & & 2017 & & \\
\hline $200 \mathrm{mgL}^{-1}$ & $46.76 \mathrm{c}$ & $10.68 \mathrm{a}$ & $0.720 \mathrm{e}$ & $14.84 \mathrm{a}$ & $45.90 \mathrm{a}$ & $48.40 \mathrm{~b}$ & $11.16 \mathrm{a}$ & $0.710 \mathrm{~d}$ & $15.71 \mathrm{a}$ & $46.75 \mathrm{a}$ \\
\hline $400 \mathrm{mgL}^{-1}$ & $49.97 \mathrm{a}$ & $10.38 \mathrm{ab}$ & $0.778 \mathrm{bcd}$ & $13.34 b$ & $44.45 \mathrm{ab}$ & $50.04 \mathrm{a}$ & $10.76 \mathrm{ab}$ & $0.795 \mathrm{bc}$ & $13.54 b$ & $45.05 \mathrm{abc}$ \\
\hline $2 \mathrm{mlL}^{-1}$ & $47.75 b c$ & $10.37 \mathrm{ab}$ & $0.805 \mathrm{ab}$ & $12.88 \mathrm{bcd}$ & $44.20 \mathrm{ab}$ & $48.80 \mathrm{ab}$ & $10.80 \mathrm{ab}$ & $0.830 \mathrm{ab}$ & $13.02 \mathrm{~b}$ & $46.63 \mathrm{a}$ \\
\hline $4 \mathrm{mlL}^{-1}$ & $46.24 \mathrm{~cd}$ & $10.03 \mathrm{bcd}$ & $0.798 \mathrm{ab}$ & $12.58 \mathrm{~cd}$ & $42.22 \mathrm{bc}$ & $46.25 \mathrm{~cd}$ & $10.40 \mathrm{bc}$ & $0.780 \mathrm{c}$ & $13.35 b$ & $44.48 b c$ \\
\hline $50 \mathrm{mlL}^{-1}$ & $44.42 \mathrm{de}$ & $10.07 \mathrm{bc}$ & $0.765 \mathrm{~cd}$ & $13.18 \mathrm{bc}$ & $41.08 \mathrm{c}$ & $44.45 \mathrm{e}$ & $10.29 \mathrm{bc}$ & $0.640 \mathrm{e}$ & $16.09 \mathrm{a}$ & $43.92 \mathrm{c}$ \\
\hline $100 \mathrm{mlL}^{-1}$ & $49.46 \mathrm{ab}$ & $9.75 \mathrm{~cd}$ & $0.755 d$ & $12.91 b c$ & $42.50 \mathrm{bc}$ & $47.78 \mathrm{bc}$ & $9.46 \mathrm{~d}$ & $0.730 \mathrm{~d}$ & $12.98 b$ & $45.90 \mathrm{ab}$ \\
\hline $5000 \mathrm{mgL}^{-1}$ & $46.06 \mathrm{~cd}$ & $9.00 \mathrm{e}$ & $0.785 \mathrm{abc}$ & $11.49 \mathrm{e}$ & $37.91 d$ & $45.67 \mathrm{de}$ & $10.02 \mathrm{c}$ & $0.725 \mathrm{~d}$ & $13.83 b$ & $43.35 \mathrm{c}$ \\
\hline $10000 \mathrm{mgL}^{-1}$ & $47.65 \mathrm{bc}$ & $9.90 \mathrm{~cd}$ & $0.808 \mathrm{a}$ & $12.26 \mathrm{~d}$ & $42.22 \mathrm{bc}$ & $47.65 \mathrm{bc}$ & $10.08 \mathrm{c}$ & $0.838 \mathrm{a}$ & $12.02 \mathrm{c}$ & $45.05 \mathrm{abc}$ \\
\hline Control & $44.12 \mathrm{e}$ & $9.67 \mathrm{~d}$ & $0.768 \mathrm{~cd}$ & $12.63 \mathrm{~cd}$ & $43.51 b$ & $45.25 \mathrm{de}$ & $10.00 \mathrm{c}$ & $0.840 \mathrm{a}$ & $11.93 \mathrm{c}$ & $44.07 \mathrm{c}$ \\
\hline L.S.D at $0.05 \%$ & 1.83 & 0.38 & 0.029 & 0.64 & 2.27 & 1.59 & 0.51 & 0.037 & 0.88 & 1.71 \\
\hline
\end{tabular}

Values followed by the same letter within a column are not significantly different at L.S.D, $P \leq 0.05$ level of probability

${ }^{\mathrm{e}}$ The probability of two genotypes or more having similar SSR profiles 


\section{Leaf area index of navel orange leaves:}

Data are presented in Table (6) showed that SA at $200 \mathrm{mg} / \mathrm{l}$ sprays significantly increased leaf area index, followed by SA at $400 \mathrm{mg} / \mathrm{l}$ and kaolin at all of concentrations during two seasons compared with the control. Spraying RRE at $100 \mathrm{ml} / 1$ or JO at $4 \mathrm{ml} / 1$ markedly enhanced leaf area, but other treatments did not show significant effect than the control.

\section{Leaf chlorophyll value:}

As shown in Table (6), leaf chlorophyll values enhanced by all treatments in comparison with the control. The highest increment leaf chlorophyll value was obtained from treatment with KPF $(10000 \mathrm{mg} / \mathrm{l})$ in both seasons, and RRE at $50 \mathrm{ml} / 1$ only in the second season. Leaf chlorophyll value significantly increased affected with spraying SA at $200 \mathrm{mg} / \mathrm{l}, \mathrm{KPF}$ at 5000 $\mathrm{mg} / \mathrm{l}$ and $\mathrm{RRE}$ at $100 \mathrm{ml} / \mathrm{l}$ during 2016 \& 2017 seasons. While, the lowest chlorophyll value was obtained from sprays JO $(2 \mathrm{ml} / \mathrm{l})$ in two seasons. These results are agreed with those obtained by El-Gioushy (2016) who worked on SA.

Table (6): Effect of some biological stimulants and kaolin particles on leaf area index and chlorophyll value of Washington navel orange during 2016 and 2017 seasons

\begin{tabular}{|c|c|c|c|c|c|}
\hline \multirow{2}{*}{\multicolumn{2}{|c|}{ Treatments, Conc. }} & \multicolumn{2}{|c|}{ Leaf area index $\left(\mathrm{cm}^{2}\right)$} & \multicolumn{2}{|c|}{ Chlorophyll SPAD values } \\
\hline & & 2016 & 2017 & 2017 & 2017 \\
\hline \multirow{2}{*}{ SA } & $200 \mathrm{mgL}^{-1}$ & $36.86 \mathrm{a}$ & $36.54 \mathrm{a}$ & $74.01 \mathrm{abc}$ & $75.98 \mathrm{ab}$ \\
\hline & $400 \mathrm{mgL}^{-1}$ & $34.70 \mathrm{ab}$ & $34.64 \mathrm{ab}$ & $73.07 \mathrm{bc}$ & $74.19 \mathrm{~b}$ \\
\hline \multirow{2}{*}{ JO } & $2 \mathrm{mlL}^{-1}$ & $31.18 \mathrm{~cd}$ & $30.40 \mathrm{c}$ & $67.41 \mathrm{~d}$ & $70.20 \mathrm{c}$ \\
\hline & $4 \mathrm{mlL}^{-1}$ & $33.00 \mathrm{bcd}$ & $33.38 b$ & $72.67 \mathrm{c}$ & $74.60 \mathrm{~b}$ \\
\hline \multirow{2}{*}{ RRE } & $50 \mathrm{mlL}^{-1}$ & $29.84 \mathrm{~cd}$ & $29.80 \mathrm{c}$ & $75.42 \mathrm{abc}$ & $77.97 \mathrm{a}$ \\
\hline & $100 \mathrm{mlL}^{-1}$ & $34.00 \mathrm{abc}$ & $33.34 \mathrm{~b}$ & $75.14 \mathrm{abc}$ & $76.77 \mathrm{ab}$ \\
\hline \multirow{2}{*}{ KPF } & $5000 \mathrm{mgL}^{-1}$ & $36.15 \mathrm{ab}$ & $35.70 \mathrm{ab}$ & $75.87 \mathrm{ab}$ & $77.15 \mathrm{ab}$ \\
\hline & $10000 \mathrm{mgL}^{-1}$ & $36.25 \mathrm{ab}$ & $35.64 \mathrm{ab}$ & $76.73 a$ & $78.03 a$ \\
\hline \multicolumn{2}{|c|}{ Control } & $31.38 \mathrm{~d}$ & $29.99 \mathrm{c}$ & $68.36 \mathrm{~d}$ & $70.12 \mathrm{c}$ \\
\hline \multicolumn{2}{|c|}{ L.S.D at $0.05 \%$} & 3.31 & 2.93 & 3.17 & 3.10 \\
\hline
\end{tabular}

Values followed by the same letter within a column are not significantly different at LSD, $\mathrm{P} \leq 0.05$ level of probability

Gharaghani et al. (2018) mentioned that application of kaolin on Persian walnut trees increased leaf area and chlorophyll content and these results support the findings stated above in this study.

Radish extract effects on having a high chlorophyll content as measured by SPAD may be due to their content of 4-methylthio-3-butenyl isothiocyanate, linoleic acid, monoacylglycerols, glucose and particularly $\beta$-sitosterol (Ragasa et al., 2015). In which is a member of the phytosterols very close to brassinosteroids in structure and that may explain the stimulating effect of radish extracts on chlorophyll formation because brassinosteroids promotes increasing chlorophyll content in plants (Yuqin et al., 1994).

\section{Leaf nutrient content (\%):}

Data in Table (7) indicated that foliar application of KPE and SA at $200 \mathrm{mg} / \mathrm{l}$ increased N content in navel orange leaves than that of the control. Spraying kaolin at $10000 \mathrm{mg} / \mathrm{l}$ gave the highest $\mathrm{N}$ content in leaves compared to untreated ones in the two seasons. All of other treatments moderately enhanced $\mathrm{N}$ level content compared to control.

Concerning P content data showed that KPE and SA increased $\mathrm{P}$ values than that of the control. However, other treatments slightly improved P content compared with control.

Potassium values in leaves of navel orange increased by RRE at $50 \mathrm{ml} / 1(0.92 ; 0.99 \%)$ in both seasons and $\mathrm{JO}$ at $2 \mathrm{ml} / 1(0.91 ; 0.95 \%)$ in the $1^{\text {st }}$ season that those of control, respectively, .

Level of Ca content in Table (7) increased by most investigated treatments compared to the untreated trees, except with SA at $400 \mathrm{mg} / \mathrm{l}$ and $\mathrm{JO}$ at $4 \mathrm{ml} / \mathrm{l}$, where gave the lowest $\mathrm{Ca}$ values compared with control. The highest leaf $\mathrm{Ca}$ content was obtained from spraying JO at $2 \mathrm{ml} / 1$ (6.0 and $6.1 \%)$ followed by treatment RRE at $50 \mathrm{ml} / 1$ (5.9 and 5.68\%) in both seasons, respectively.

The present results are in agreement with ElGioushy (2016) who stated that SA application enhanced nutritional content at different concentrations of Washington navel orange. 
Table (7): Effect of some biological stimulants on leaf nutrient contents (\%) of Washington navel orange during 2016 and 2017 seasons

\begin{tabular}{|c|c|c|c|c|c|c|c|c|c|}
\hline \multirow{2}{*}{\multicolumn{2}{|c|}{ Treatments, Conc. }} & $\mathbf{N} \%$ & P \% & K\% & $\mathrm{Ca} \%$ & $\mathbf{N} \%$ & P \% & K\% & $\mathrm{Ca} \%$ \\
\hline & & \multicolumn{4}{|c|}{2016} & \multicolumn{4}{|c|}{2017} \\
\hline \multirow{2}{*}{$\mathbf{S A}$} & $200 \mathrm{mgL}^{-1}$ & $3.31 b$ & $0.15 b$ & $0.79 \mathrm{bc}$ & $5.23 \mathrm{bc}$ & $3.32 b$ & $0.15 b$ & $0.83 \mathrm{e}$ & $5.38 \mathrm{bcd}$ \\
\hline & $400 \mathrm{mgL}^{-1}$ & $2.76 \mathrm{f}$ & $0.09 \mathrm{c}$ & $0.68 \mathrm{~d}$ & $4.10 \mathrm{e}$ & $2.82 \mathrm{f}$ & $0.09 \mathrm{c}$ & $0.72 \mathrm{~h}$ & $4.30 \mathrm{f}$ \\
\hline \multirow{2}{*}{ JO } & $2 \mathrm{mlL}^{-1}$ & $3.12 \mathrm{~d}$ & $0.03 \mathrm{e}$ & $0.91 \mathrm{a}$ & $6.00 \mathrm{a}$ & $3.26 \mathrm{c}$ & $0.03 \mathrm{f}$ & $0.95 b$ & $6.10 \mathrm{a}$ \\
\hline & $4 \mathrm{mlL}^{-1}$ & $3.24 \mathrm{c}$ & $0.03 \mathrm{e}$ & $0.78 b c$ & 4.40de & $3.17 \mathrm{~d}$ & $0.03 \mathrm{f}$ & $0.81 \mathrm{f}$ & $4.68 \mathrm{e}$ \\
\hline \multirow{2}{*}{ RRE } & $50 \mathrm{mlL}^{-1}$ & $3.16 \mathrm{~d}$ & $0.09 \mathrm{c}$ & $0.92 \mathrm{a}$ & $5.90 \mathrm{ab}$ & $3.17 \mathrm{~d}$ & $0.10 \mathrm{c}$ & $0.99 \mathrm{a}$ & $5.68 b$ \\
\hline & $100 \mathrm{mlL}^{-1}$ & $3.04 \mathrm{e}$ & $0.04 \mathrm{e}$ & $0.82 \mathrm{bc}$ & $4.90 \mathrm{~cd}$ & $3.09 \mathrm{e}$ & $0.05 \mathrm{e}$ & $0.87 \mathrm{~d}$ & $5.23 \mathrm{~cd}$ \\
\hline \multirow{2}{*}{ KPF } & $5000 \mathrm{mgL}^{-1}$ & $3.31 b$ & $0.16 b$ & $0.84 \mathrm{ab}$ & $4.9 \mathrm{~cd}$ & $3.34 \mathrm{~b}$ & $0.16 b$ & $0.90 \mathrm{c}$ & $5.10 \mathrm{~d}$ \\
\hline & $10000 \mathrm{mgL}^{-1}$ & $3.48 \mathrm{a}$ & $0.30 \mathrm{a}$ & $0.77 \mathrm{bc}$ & $5.58 \mathrm{abc}$ & $3.53 \mathrm{a}$ & $0.31 \mathrm{a}$ & $0.87 \mathrm{~d}$ & $5.53 \mathrm{bc}$ \\
\hline \multicolumn{2}{|c|}{ Control } & $2.50 \mathrm{~g}$ & $0.07 \mathrm{~d}$ & $0.74 \mathrm{~cd}$ & 4.30de & $2.53 \mathrm{~g}$ & $0.07 \mathrm{~d}$ & $0.78 \mathrm{~g}$ & $4.53 \mathrm{ef}$ \\
\hline \multicolumn{2}{|c|}{ L.S.D at $\mathbf{0 . 0 5 \%}$} & 0.07 & 0.02 & 0.08 & 0.69 & 0.03 & 0.01 & 0.01 & 0.33 \\
\hline
\end{tabular}

Values followed by the same letter within a column are not significantly different at L.S.D, P $\leq 0.05$ level of probability

\section{CONCLUSION}

Consequently, from the present results clearly approved that Washington navel orange trees treated with salicylic acid (SA) at $200 \mathrm{mg} / \mathrm{l}$ enhanced fruit retention, productivity, physico-chemical properties by increasing fruit firmness, juice content, TSS, ascorbic acid, TSS/TA ratio and decreasing acidity. In addition, it improved leaf area index and nutritional status followed by kaolin treatment at all concentrations and $\mathrm{JO}$ at $2 \mathrm{ml} / \mathrm{l}$.

\section{REFERENCES}

AOAC (1995). Association of Official Agricultural Chemists, Official Methods of Analysis $14^{\text {th }}$ Ed. Washington, D.C, U.S.A.

Ahmad, P., S. Rasool, A. Gul, S. A. Sheikh, N. A. Akram, M. Ashraf, A. M. Kazi and S. Gucel (2016). Jasmonates: Multifunctional Roles in Stress Tolerance. Frontiers in Plant Science, 7(813): 1-15.

Ahmad, S., Z. Singh and Z. Iqbal (2013). Effect of preharvest sprays of salicylic acid on the shelf life and quality of 'Lane Late' sweet orange "Citrus sinensis L." cold storage. Proc. $7^{\text {th }}$ international postharvest symposium Eds. H. Abdullah and M.N. Latifah-Acta Hort. 1012, ISHS, pp. 103-112.

Ali, M. S. M. and M. A. M. Elhamahmy (2015). Impact of kaolin particles film coating and UV-C treatments on storability and quality of 'Washington navel' orange during long-period cold storage. Zagazig J. Agric. Res., 42(5): 1081-1099.

Ashraf, M. Y., M. Ashraf, M. Akhtar, K. Mahmood and M. Saleem (2013). Improvement in yield, quality and reduction in fruit drop in Kinnow "Citrus reticulata Blanco" by exogenous application of plant growth regulators, potassium and Zinc. Pak. J. Bot., 45(SI): 433440.

Balbontín, C., C. Gutiérrez, M. Wolff and C. R. Figueroa (2018). Effect of abscisic acid and methyl Jasmonate preharvest applications on fruit quality and cracking tolerance of sweet cherry. Chilean Journal of Agricultural Research, 78(3): 438-446.

Benedict, H. M. and R. Swidler (1961). Nondestructive methods for estimating chlorophyll content of leaves. Science, 133(3469): 2015-2016.

Bevington, K., M. Treeby and R. Storey (1993). Albedo breakdown in oranges. Queensland Citrus bulletin spring: 16-19.

Braham, M., E Pasqualini and N. Ncira (2007). Efficacy of kaolin, spinosad and malathion against Ceratitis capitata in Citrus orchards. Bulletin of Insectology, 60(1): 39-47.

Chapman, H. D. and P. F. Pratt (1961). Methods of analysis for soils, plants and waters. (Riverside Ca.): University of California, Division of Agricultural Science, pp. 309.

Curtis, I. S. (2003). The noble radish: past, present and future. Trends Plant Sci., 8(7): 305-307.

El Zayat, H. E., Fatma E. Ibrahim and Sahar M. A. ElEtreby (2017). The effectiveness of preharvest foliar spray of some biological materials on keeping quality of Valencia orange fruits during cold storage. Egypt. J. Agric. Res., 95 (3): 1131-1143.

El-Boray, M. S., M. F. M. Mostafa, S. E. Salem and O. A. O. El-Sawwah (2015). Improving yield and fruit quality of Washington navel orange 
using foliar spray applications of some natural biostemulants. J. Plant Production, Mansura Univ., 6(8):1317-1322.

El-Gioushy, S. F. (2016). Productivity, fruit quality and nutritional status of Washington navel orange trees as influenced by foliar application with salicylic acid and potassium silicate combinations. Journal of Horticultural Science \& Ornamental Plants, 8(2): 98-107.

Ennab, H. A., S. A. El-Sayed and M. M. S. Abo ElEnin (2017). Effect of kaolin applications on fruit sunburn, yield and fruit quality of Balady mandarin "citrus reticulata, Blanco". Menoufia. J. Plant Prod., 2: 129-138.

Gharaghani, A., A. M. Javarzari and K. Vahdati (2018). Kaolin particle film alleviates adverse effects of light and heat stresses and improves nut and kernel quality in Persian walnut. Scientia Horticulturae, 239: 35-40.

Glenn, D. M. and G. J. Puterka (2010). Particle films: A new Technology for Agriculture. Horticultural Reviews, 31: 1-44.

Habasy, R. E. Y. (2015). Effect of spraying salicylic acid on fruiting of Valencia orange trees. Alex. J. Agric. Res., 60(3): 119-126.

Iqbal, Z., Z. Singh, R. Khangura and S. Ahmad (2012). Management of citrus blue and green moulds through application of organic elicitors' Australasian Plant Pathol., 41(1): 69-77.

Ismail, A., M. Riemann and P. Nick (2012). The Jasmonate pathway mediates salt tolerance in grapevines. Journal of Experimental Botany, 36(5): 2127-2139.

Javaid, A. and A. Bashir (2015). Radish extract as natural fungicides for management of fusarium oxysporum f. Sp. Lycopersici, the cause of tomato wilt. Pak. J. Bot., 47(SI): 321-324.

Jifon, J. L. and J. P. Syvertsen (2003). Kaolin particle film applications can increase photosynthesis and water use efficiency of "Ruby Red" grapefruit leaves. J. Amer. Soc. Hort. Sci., 128(1): 107-112.

Jackson, M. L. (1962). Soil Chemical Analysis. Constable and Company, Ltd.

Karla, Y. P. (1998). Handbook of reference for plant analysis. Boca Raton, Boston, London, New York, Washington, D.C. CRC Press, pp. 1291.

Khan, A. S., A. U. Malik, M. A. Pervez, B. A. Saleem, I. A. Rajwana, T. Shaheen and R. Anwar (2009). Foliar application of low-biuret urea and fruit canopy position in the tree influence the leaf nitrogen status and physico-chemical characteristics of Kinnow mandarin (Citrus reticulata Blanco). Pakistan Journal of Botany, 41(1):73-85.

Kittikorn M. and S. Kanlayanarat (2004). Relationships between Jasmonates and chilling injury in mangosteens are affected by spermine. HortScience, 39(6): 1346-1348.

Kucuker E. and B. Ozturk (2014). Effects of preharvest methyl Jasmonate treatment on postharvest fruit quality of JOpanese plums. African J. of Traditional Complement and alternative medicines, 11(6): 105-117.

Lahey, K. A., R. Yuan, J. K. Burns, P. P. Ueng, L. W. Timmer and K. R. Chung (2004). Induction of phytohormones and differential gene expression in citrus flowers infected by the fungus Colletotrichum acutatum. Molecular Plant-Microbe Interactions, 17(12): 13941401.

Maletiska, P. A., G. D. Nanos and G. G. Stravroulakis (2015). Kaolin effect on fresh and canned clingstone peach fruit quality and inorganic element composition. ISHS Acta Horticulturae 1084: VIII International Peach Symposium, 1084: 321-326.

Mirdehghan, S. H., G. Vatanparast, H. R. Karimi and M. H. Vazifeshenas (2012). Preharvest foliar application of methyl Jasmonate, salicylic acid and potassium sulfate on improving quality of pomegranate fruit. II International symposium on the pomegranate. ZaragosaCIHEAM, 103: 183-189.

Nelson, P. W. and L. E. Sommers (1982). Total carbon, organic carbon and organic matter. In: Methods of Soil Analysis. Part 2 Chemical and Microbiological Properties (Eds.): A. L. Page, R. H. Miller, D. R. Keeney. Am. Soc. Agron., pp. 539-579.

Peterson, T. A., T. M. Blackmer, D. D. Francis and J. S. Schepers (1993). Using a Chlorophyll Meter to Improve N Management. Nebguide. Cooperative Extension Service, University of Nebraska, Lincoln Extension, 1353.

Piotrowskaa, A., A. Bajguz, B. Godlewska-Zyłkiewicz, R. Czerpak, M. Kaminska (2009). Jasmonic acid as modulator of lead toxicity in aquatic plant Wolffia arrhiza (Lemnaceae). Environmental and Experimental Botany, 66(3): 507-513.

Ragasa, C. Y., V. D. Ebajo Jr., M. Carmen S. Tan, R. BrklJOča and S. Urban (2015). Chemical constituents of Raphanus sativus. Der Pharma Chemica, 7(11): 354-357.

Rosati, A. (2007). Physiological effects of Kaolin Particle Film Technology: A Review. Functional plant Science and Biotechnology, 1(1): 100-105.

Ruiz, R., A. Garcia-Luis, C. Monerri and J. L. Guardiola (2001). Carbohydrate availability in relation to fruitlet abscission in citrus. Annals of Botany, 87(6): 805-812.

Sabry, G. H., H. A. El-Helw and A. S. Abd El-Rahman (2011). A study on using jasmine oil as a breaking bud dormancy for flame seedless grapevines. Report and Opinion, 3(2): 48-56.

Sanders, P. M., P. Y. Lee, J. D. Boone, T. P. Beals, E. W. Weiler and R. B. Goldberg (2000). The Arabidopsis delayed dehiscencel gene encodes an enzyme in the Jasmonic acid synthesis pathway. Plant Cell, 12(7): 10411061. 
Schaller, A. and A. Stintzi (2009). Enzymes in Jasmonate biosynthesis - structure, function, regulation. Phytochemistry, 70(13-14): 15321538.

Schlink, K. (2011). Gene expression profiling in wounded and systemic leaves of Fagus sylvatica reveals up-regulation of ethylene and Jasmonic acid signalling. Plant Biol (Stuttg), 13(3), 445-452

Skewes, M. (2014). Citrus Drought Survival and Recovery Trial. Horticulture Australia Ltd, Project Number: CT08014. Pp. 1-63.

Steel, R. G. D., J. H. Torrie and D. A. Deekey (1997). Principles and Procedures of Statistics: A Biometrical Approach. $3^{\text {rd }}$ Edn. McGraw Hill Book Co. Inc., New York.

USDA GAIN Reports (2016). Foreign Agricultural Service, Citrus Annual. 18 Dec. 2016, pp. 19.

USDA GAIN Reports (2017). Foreign Egypt citrus manual. Global agricultural information network-date 29 Nov. 2017 (publication made by USDA staff).

USDA GAIN Reports (2018). Foreign. Agricultural Service. Citrus: World Markets and Trade July 2018, pp. 1- 11.

Vick, B. A and D. Zimmerman (1984). Biosynthesis of jasmonic acid by several plant species. Plant physiology, 75: 458-461.

Westwood, M. N. (1978). Temperate zone pomology. W. H. Freeman and Company, San Francisco, USA.
Wilde, S. A., R. B. Corey, J. C. Lyer and G. K. Voigt (1985). Soils and Plant Analysis for Tree Culture. $3^{\text {rd }}$ Ed. Oxford. IBH. New Delhi, pp: $1-218$.

Yuqin, W., L. Wenhua, Xu Rujuan and Yujuz (1994). Effect of epibrassinolide on growth and fruit quality of watermelon. Plant physiology Communications (China), 30(6), pp. 423-425.

Zaghloul, A. E., H. A. Ennab and Mervat A. El-Shemy (2017). Influence of kaolin sprays on fruit quality and storability of Balady mandarin. Alexandria Science exchange Journal, 38(4): 661-670.

Zaghloul, A. E. and E. A. Moursi (2017). Effect of irrigation scheduling under some biostimulants foliar application for Navel orange trees on some water relations, productivity, fruit quality and storability in the North Nile Delta region. Alexandria Science exchange Journal, 38(4): 671-686.

Zaki, Z. A., A. R. M. Yousef, E. A. A. Abd El-Moneim and H. E. Emam (2017). Effect of some natural extracts on maintaining quality of zaghloul date palm fruits during cold storage. Middle East J. Agric. Res., 6(2): 464-473

Zarins, I., M. Daugavietis and J. halimona (2009). Biological activity of plant extracts and their application as ecologically harmless biopesticide. Scientific works of the Lithuanian institute of horticulture and Lithuanian university of Agriculture. Sodininkyste ir Darzininkyste, 28(3): 269280 .

\section{تأثير بعض المنشطات البيولوجية وجزيئات الكاؤلين على الثمار المتبقية والإتتاجية وجودة الثمار في أثجار البرتقال بسرة واشنجطن

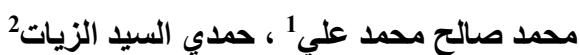

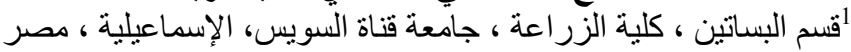

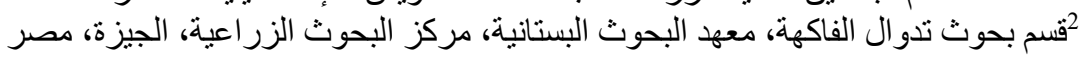

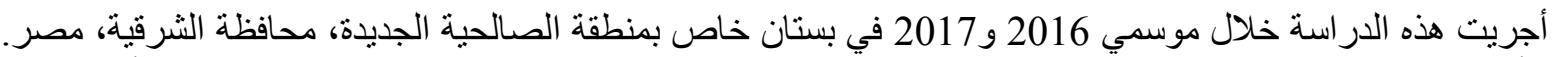

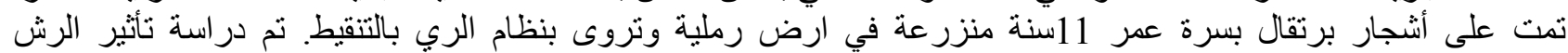

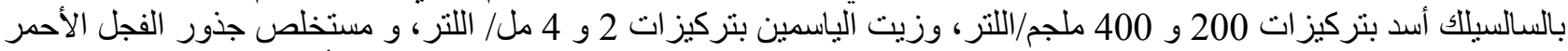

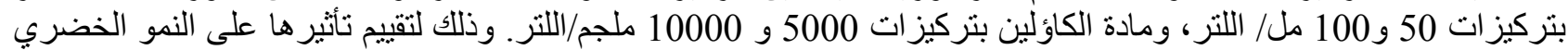

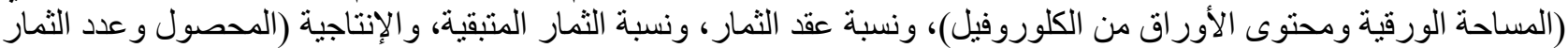

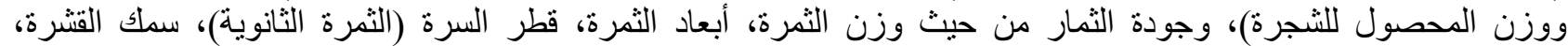

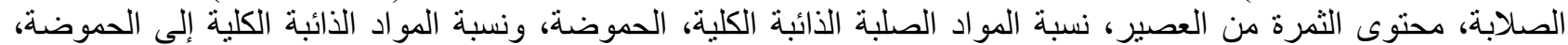

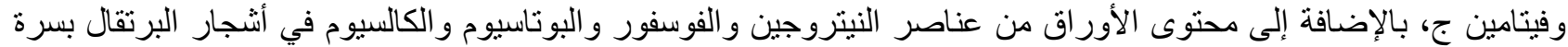

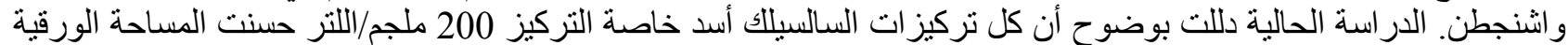

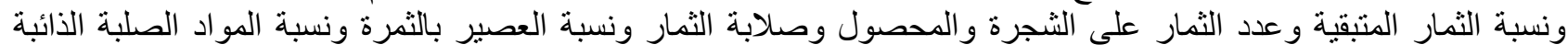

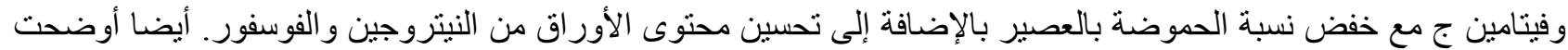

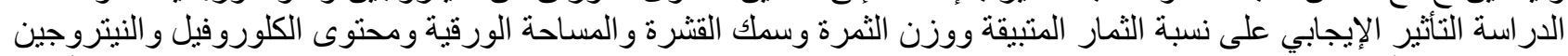

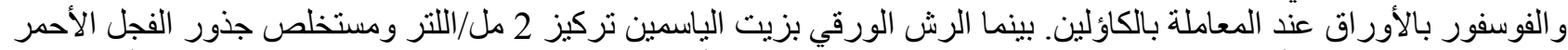

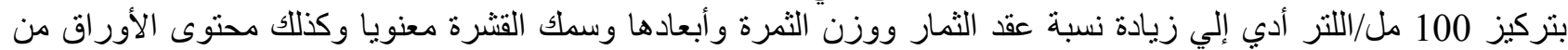
الكالسيوم وخفض نسبة الحموضة التئ. 